at wave-length $3200 \mathrm{~A}$. (maximum for $p$-nitrophenol) and then at wave-length $2780 \mathrm{~A}$. (maximum for parathion). With the first examination we obtain maximum absorption in the location of the parathion spot; the contrary occurs, on the other hand, when the examination is made with wave-length $2780 \mathrm{~A}$. Sometimes the impurities still present in the extract alter the form of the spot, which becomes considerably flatter or wider : notwithstanding, the $R_{F}$ value is not substantially modified, and, furthermore, the examination with the two ultra-violet ray lamps and an eventual successive transformation of the parathion into $p$-nitrophenol by ammonia vapour equally allow identification.

I am grateful to Dr. R. M. de Leo for his co-operation. Further details will be published elsewhere.

\section{Angelo Fiort}

Istituto di Medicina Legale e delle Assicurazioni, Università di Padova. April 30.

1 Averell, P. R., and Norris, M. V, Anal. Chem, 20, 753 (1948).

' Fretwurst, F., and Naeve, W., Arch. Toxikol., 15, 185 (1955).

"Kuhn, R., and Wieland. T., Ber., 73, 962 (1940), as quoted in Lederer, E., and Lederer, M., "Ćhromatography" (Elsevier, Amsterdam, 1953)

${ }^{4}$ Markham, R., and Smith, J. D., Biochem. J., 45, 294 (1949).

' Pfeil, F., and Goldbach, H. J., Klin. Wschr., 31, 1011 (1953).

- Kaiser, H., and Haag, Th. (quoted by Schmidt).

' Schmidt, F., Arch. Toxikol., 15, 361 (1955).

${ }^{8}$ Metcalf, F. L., and March, R. B., Science, 117, 527 (1953).

'Tennent, D. M., Whitla, J. B., and Florey, K., Anal. Chem., 23, 1748 (1951).

\section{Ascorbic Acid Content in Fruits of Myrciaria glomerata Berg.}

THe fruit of the Brazilian plant Myrciaria glomerata Berg. has proved to be very rich in ascorbic acid. The ascorbic acid content was determined in the extract obtained by running the fruits (as a whole or in parts) in a blend or for 2 min. ; a 0.4 per cent oxalic acid solution was used for preventing oxida. tion during the extraction period and subsequent determination; ascorbic acid was assayed by the $2: 6$-dichlorophenol-indophenol method according to the technique described by Leme and Malavolta ${ }^{1}$.

A marked difference in vitamin $C$ content was observed in fruits from trees exposed to full sunlight when compared to those from shaded trees.

\begin{tabular}{ccc} 
& \multicolumn{3}{c}{ Mgm, ascorbic acid/100 gm. } \\
Trce No. & Full sunlight & Shaded \\
1 & 2,417 & $717 \cdot 3$ \\
2 & 2,389 & $838 \cdot 6$ \\
3 & 2,322 & $560 \cdot 8$
\end{tabular}

Assays made with fruits at different stages of maturity gave the following results:

$\begin{array}{lc}\text { State of maturity } & \text { Mgm. ascorbic acid/100 gm. } \\ \text { Green fruits } & 2,716 \\ \text { Fully developed fruits } & 2,391 \\ \text { Ripe fruits } & 2.417\end{array}$

Green fruits had thus a higher vitamin C content than either partially or completely ripe fruits; the difference between the last two types was not statistically significant.

Different parts of the fruit that were assayed separately had the following ascorbic acid content :

$\begin{array}{cc}\text { Part of the fruit } & \text { Mlgm. ascorbic acid/100 gm. } \\ \text { Peel (without seeds) } & 2,482 \\ \text { Pulp (wi } & 3,018\end{array}$

It is fortunate that the edible portion of the fruit, namely, the pulp, is richer than the peel.

The results herein reported show that the fruits of Myrciaria glomerata have the highest vitamin $\mathrm{C}$ content found among edible fruits of the family Myrtaceae; they are also among the fruits richest in this vitamin, being surpassed only by the hips of wild roses and by fruits of Malpighia spp.

E. Malavolta

J. LEME, JUN.

J. T. A. GURGEL

E.S.A. 'Luiz de Queiroz',

University of S. Paulo,

Piracicaba, S. Paulo, Brazil.

Instituto Agronômico,

Campinas, S. Paulo. Brazil.

${ }^{1}$ Leme, jun., J., and Malavolta, E., An. Esc. Agric. Queiroz, 7, 116 $(1950)$.

\section{Development of the Long Forms of Bacteria}

Numerous methods of inducing long forms in aerobic and anaerobic bacteria have now been described ${ }^{\mathbf{x} 2}$. One of the standard techniques of maintaining these forms is to grow the organisms beneath an agar block, that is, under microaerophilic conditions.

During the course of large numbers of experiments with shake cultures in quill tubes $(3 \mathrm{~mm}$. internal diameter), the medium being covered with various substances, the development of long forms has been readily observed. An account of this work is being prepared for publication.

Utilizing poor media (agar containing 2 per cent nutrient broth) it was observed that, with twonty different aerobic species (all catalase-positive) examined, a series of disks appeared below the meniscus at various depths up to $12 \mathrm{~mm}$. (that is, to the depth of normal oxygen penetration). This phenomenon did not occur in this medium with catalase-negativo organisms. When these disks are sectioned, long forms and typical $L$-bodies can always be seen (Figs. 1 and 2), sometimes for up to six week: after incubation. The fact that sunlight increases the depths of the disks ${ }^{3}$ suggested that the formation of hydrogen peroxide is the probable factor involved. If hydrogen peroxide is placed at the surface prior to incubation the disks appear at a very much lower level, whereas with catalase on top, growth occurs on the surface of the medium and no disks develop

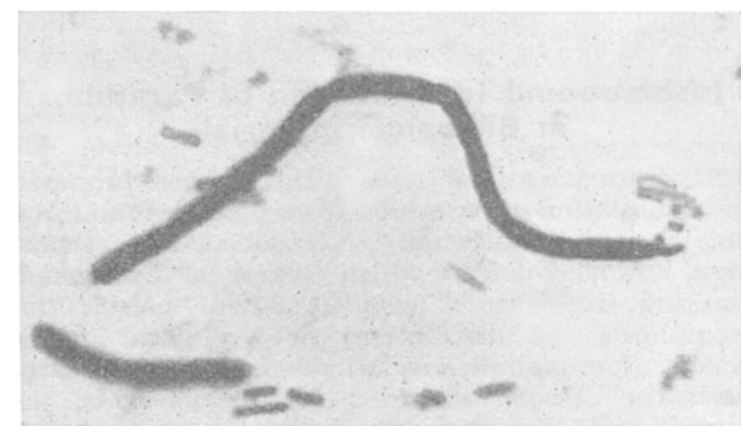

Fig. 1. B. anthracis showing normal and long forms $(\times 1,400)$ 